\title{
Quality of work life practices of women employees in the garment companies in Tamil Nadu
}

\author{
P. Marish kumar \\ Associate Professor, Dept. of Management Studies, Vinayaka Mission's Kirupananda Variyar Engineering College, Salem, \\ Tamilnadu, India
}

Corresponding Author:

Email: mailmarish@gmail.com

\begin{abstract}
Quality of work life is a general statement that over all areas of a employee's thoughts about all parts, or cooperate with financial motivations and welfares, wellbeing, security, work environment, and key importance in a man's life. In this topic deals with several characteristics of job climate, which empowers the human resource development. The opportunities of quality of work life measure which originally included only work restructure efforts based on the socio-technical systems approach has progressively extended very much so as to include a wide variety of interventions such as quality circles, suggestion schemes, employee participation, empowerment, autonomous work teams etc. The quality of work life in an organization is greatly influenced by the ethical and moral values prevalent in the organization. However, more no. of enterprises, both in India and abroad, tend to disregard the importance of such values.
\end{abstract}

Keywords: Human Resource Management, Job satisfaction, Life satisfaction, Quality of Work life (QWL).

\section{Introduction}

Quality of work life is a general statement that over all areas of a employee's thoughts about all parts, or cooperate with financial motivations and welfares, wellbeing, security, work environment, and key importance in a man's life. It is a process by which an organisation endeavors to release the imaginative capability of its human by including them in choices influencing their work lives. Its objectives are not just outward concentrating of the enhancement of results and performance. The vital or most important segment of value work life change is the existence of a genuine opportunity for individuals at any level in the organization to influence their working environment. It focuses on creating a good human work atmosphere where employees work mutually and contribute to organizational objectives. The indicators of quality of work life are job engrossment, job fulfilment and production efficiency. The developments of human resource include performance analysis, training, career planning, organization change and advancement, and quality of work life of the women employees in garment industry. In this study deals with various aspects of work environment, which facilitates the human resource development.

The quality of work life involves three most important intellectual regions namely work-related health care, proper working time and fair salary. The good and safe working atmosphere offers the source for the women employees to dynamic working. The work ought not represent a health hazard for the women employees in garment industry. The top management individuals and other management individuals, conscious of their own difficulties, risks and fundamental human rights, could reach a lot in their mutually beneficial dialogue.

\section{Importance of the study}

The quality of work life in an organization is greatly influenced by the ethical and moral values prevalent in the organization. However, a number of enterprises, both in India and abroad, tend to disregard the importance of such values. One can see the result of this in India, where there are definite signs of deterioration in the ethical and moral standards of the people practically in all walks of life. Human happiness is one of the ultimate objectives for which a business enterprise exists. But the sad truth is that although various economies in the world have seen phenomenal material progress during the last hundred years, they are still unable to achieve this human happiness. The source of the ethics in all societies has been the wisdom of its sages, seers, philosophers, thinkers and leaders.

\section{Statement of the Problem}

One of the important issue facing the world-wide nations is the quality of work life of a greater part of women workers occupied in efficient performance interest. This issue is not only one of accomplishing more prominent employee fulfillment however it additionally goes for enhancing efficiency, flexibility and general adequate success of organizations. The quality of working life movement in a broader sense seeks to achieve integration among the technological, human, organizational and society demands which are often contradictory and conflicting. The sharing the knowledge of employees in finding the solution of the problem and choices involved decision making mainly in regions attached to their work is reliable to be 
needed bond for providing superior independence and opportunity for self-direction and self-control to women workforces with the most important aim of enhancing the quality of life at work.

\section{Review of Literature}

Richard T. De George (1990) asserts that quality of work life has been carried over into the work place as concern for the quality of work life. He scales four components for analytical purposes. The first is the condition of labour; the second, the organization of the work performed; the third, the relations of the workers among themselves, with those above them and with the tools or machines with which they work; and the fourth, the attitude of the workers to work.

Wallace, (1993) study on teachers found that teachers who are more committed to the profession and its goals are less likely to be highly committed to the organization.

Zeffana (1994) surveyed 474 public and 944 private sector employees in Australia to examine the Organizational Commitment and perceived management style. Finding reveals that private sector employees had higher Organizational Commitment and scored high on flexibility, adaptation and on work group discontinuity than public sector employees.

Gupta \& parul (2010) studied on Quality of Work Life of telecom sector employees and observed whether and how the Quality of Work Life influences the level of fulfillment of representatives of telecom area. Discovered that elements identified with Quality of Work Life are affecting the work fulfillment and productivity. The elements must be concentrated were reasonable and fair compensation, satisfactory salary, solid work environment, safe working conditions, open door for self-improvement, open door for profession development, social involvement, work force integration, social pertinence of work constitutionalism in work organization and prominence of work life.

\section{Objectives of the Study}

The study has the following objectives:

1. To study the need and importance of quality of work life of employees.

2. To measure the quality of work life practices applied in the women employees in garments companies in Tamil Nadu.

3. To examine the satisfaction level of the women employees towards quality of work life in the select garment companies in Tamil Nadu.

\section{Limitations of the Study}

The present study has the following limitations.
1. Any study having a bearing on attitude, incomplete, false data and non-responses to some questions could not be avoided, however, the in any case, the researcher took most extreme efforts to limit such mistakes.

2. The quality of work life is a subject including number of exercises; the most widely familiar practices only were considered in this examination.

3. The results of the investigation is relevant for Garment Companies in Salem District. It isn't pertinent for the comparable association in different Districts and States..

\section{Research Methodology}

Testing of Hypothesis: In order to examine the perception of the women employees towards work-life balance, the following null hypotheses will be formulated and tested.

H01: There is no noteworthy relationship among the acceptance levels of the employees belonging to different demographic profiles towards factors responsible for work-life imbalance in Garment Companies in Salem

H02: The demographic variables of the employees do not have any noteworthy impact on their level of worklife balance in Garment Companies in Salem.

H03: There is no noteworthy relationship among the acceptance levels of the women employees belonging to different demographic profiles towards impact of work-life balance in Garment Companies in Salem

Research design: This study is empirical in nature based on survey method. The direct data for this study has been collected from the human resource department of the company. The Vital part of the study, the primary data was collected from 100 women employees. Questionnaire method was employed to collect primary data. The data so collected was entered in to a master table and was charted to attain at beneficial conclusion. The secondary data was collected from journals, reports and books. The scope of the study is evaluating the quality of work life among women employees in Garment Companies in Salem.

\section{Framework of Analysis}

The ultimate object of the study is evaluating the quality of work life of employees in Garment Companies in Salem. In order to find out the attitudinal differences of employees, chi-square test, analysis of one-way variance, co-efficient of variation, and percentage analyses have been employed. 


\section{Data Analysis}

A. Key Variables of Quality of work life of woman employees.

Table 1: Salary and Satisfaction towards Quality of Work Life

\begin{tabular}{|l|c|c|c|c|}
\hline \multirow{2}{*}{ Variables } & \multicolumn{3}{|c|}{ Level of Attitude } & \multirow{2}{*}{ Total } \\
\cline { 2 - 4 } & Highly Satisfied & Satisfied & Dissatisfied & \\
\hline Emoluments & 62 & 31 & 7 & 100 \\
& $(62.00)$ & $(31.00)$ & $(07.00)$ & $(100.00)$ \\
\hline $\begin{array}{l}\text { Meeting financial } \\
\text { needs }\end{array}$ & 56 & 27 & 17 & 100 \\
& $(56.00)$ & $(27.00)$ & $(17.00)$ & $(100.00)$ \\
\hline $\begin{array}{l}\text { Willing to continue } \\
\text { the present job }\end{array}$ & 55 & 26 & 19 & 100 \\
\hline $\begin{array}{l}\text { Right compensation } \\
\text { of the job }\end{array}$ & $(55.00)$ & $(26.00)$ & $(19.00)$ & $(100.00)$ \\
\hline Overall & 51 & 39 & 10 & 100 \\
& $(51.00)$ & $(39.00)$ & $(10.00)$ & $(100.00)$ \\
\hline
\end{tabular}

Source: Primary Data.

$56 \%, 31 \%$ and $13 \%$ of the respondents had highly satisfied, Satisfied and Dissatisfied attitude respectively with the wage and salary of employees in Garment Companies in Salem. Ranging from $51 \%$ to $62 \%$ of the respondents had good attitude with the emoluments, meeting financial needs, willing to continue the present job and right compensation of the job.

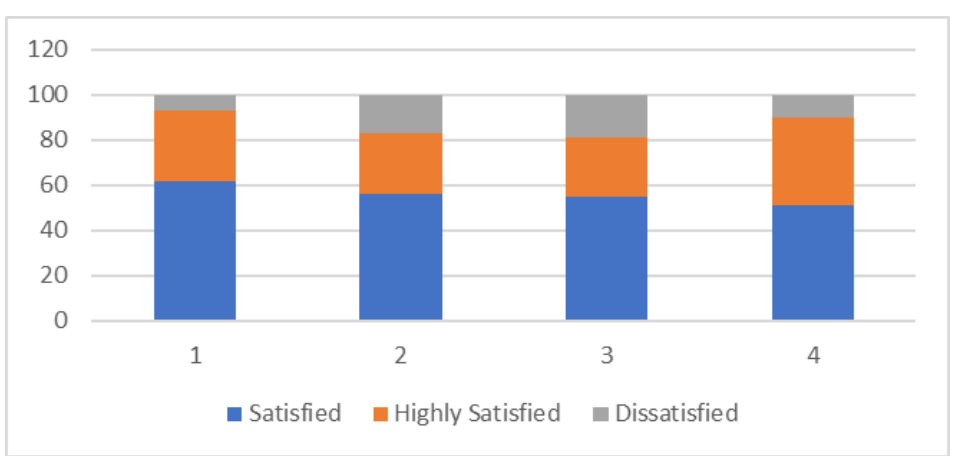

Fig. 1: Monthly Salary and Satisfaction towards Quality of Work Life

Table 2: Working Conditions and Satisfaction towards Quality of Work Life

Source: Primary Data

\begin{tabular}{|l|c|c|c|c|}
\hline \multirow{2}{*}{ Variables } & \multicolumn{3}{c|}{ Level of Attitude } & \multirow{2}{*}{ Total } \\
\cline { 2 - 4 } & Good & Fair & Poor & \\
\hline $\begin{array}{l}\text { Duties occupied by the } \\
\text { members }\end{array}$ & 54 & 34 & 12 & 100 \\
$(54.00)$ & $(34.00)$ & $(12.00)$ & $(100.00)$ \\
\hline $\begin{array}{l}\text { Risk free working } \\
\text { conditions }\end{array}$ & 56 & 35 & 9 & 100 \\
$(56.00)$ & $(35.00)$ & $(09.00)$ & $(100.00)$ \\
\hline $\begin{array}{l}\text { Over crowding and } \\
\text { neatness }\end{array}$ & 64 & 27 & 9 & 100 \\
$(64.00)$ & $(27.00)$ & $(09.00)$ & $(100.00)$ \\
\hline $\begin{array}{l}\text { Humanized working } \\
\text { conditions }\end{array}$ & 53 & 31 & 16 & 100 \\
\hline $\begin{array}{l}\text { Tolerance of noise and } \\
\text { illumination }\end{array}$ & $\begin{array}{c}53.00) \\
(40.00)\end{array}$ & $\begin{array}{c}(41.00) \\
(41.00)\end{array}$ & $\begin{array}{c}16.00) \\
(19.00)\end{array}$ & $(100.00)$ \\
\hline $\begin{array}{l}\text { Importance given to } \\
\text { individuals in the work } \\
\text { environment }\end{array}$ & $\begin{array}{c}57 \\
(57.00)\end{array}$ & $\begin{array}{c}30 \\
(30.00)\end{array}$ & $\begin{array}{c}13 \\
(1300)\end{array}$ & $(100.00)$ \\
\hline Overall & 54 & 33 & 13 & 100 \\
& $(54.00)$ & $(33.00)$ & $(13.00)$ & $(100.00)$ \\
\hline
\end{tabular}


$54 \%, 33 \%$ and $13 \%$ of the respondents had good, fair and poor attitude respectively with the safety and working conditions in Garment Companies in Salem. Ranging from $53 \%$ to $64 \%$ of the respondents had good attitude with the duties occupied by the members, risk free working conditions, overcrowding and neatness, humanized working conditions, and importance given to individuals in the work environment. About 40 per cent of the respondents had good attitude with the tolerance of noise and illumination.

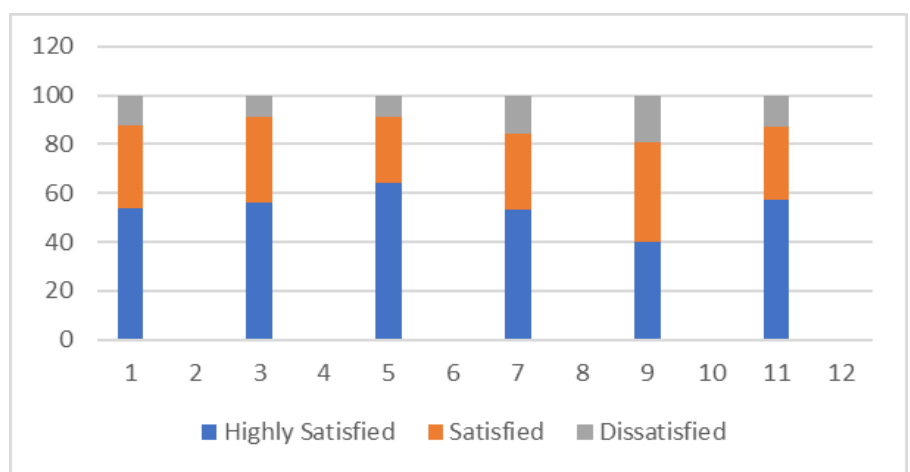

Fig. 2: Working Conditions and Satisfaction towards Quality of Work Life

Table 3: Gender and Variations in the Attitude

Source: Primary Data

\begin{tabular}{|l|c|c|c|c|}
\hline Gender & $\begin{array}{c}\text { No. of } \\
\text { Respondents }\end{array}$ & $\begin{array}{c}\text { Average } \\
\text { Attitude Score }\end{array}$ & $\begin{array}{c}\text { Standard } \\
\text { Deviation }\end{array}$ & $\begin{array}{c}\text { Co- } \\
\text { variation }\end{array}$ \\
\hline Male & 76 & 2.53 & 0.65 & 26.00 \\
\hline Female & 24 & 2.08 & 0.77 & 37.25 \\
\hline Total & 100 & 2.41 & 0.79 & 32.78 \\
\hline
\end{tabular}

Table 3 shows the variations in the attitude level of male and female employees towards quality of work life. It is inferred that the variations in the attitude level was high among female employees followed by male employees.

Table 4: Age and Variations in the Attitude

Source: Primary Data

\begin{tabular}{|l|c|c|c|c|}
\hline Age (in years) & $\begin{array}{c}\text { No. of } \\
\text { Respondents }\end{array}$ & $\begin{array}{c}\text { Average } \\
\text { Attitude Score }\end{array}$ & $\begin{array}{c}\text { Standard } \\
\text { Deviation }\end{array}$ & $\begin{array}{c}\text { Co- } \\
\text { variation }\end{array}$ \\
\hline Up to 30 & 9 & 2.11 & 0.8736 & 41.40 \\
\hline $31-40$ & 26 & 2.11 & 0.8458 & 40.08 \\
\hline $41-50$ & 44 & 2.27 & 0.6842 & 30.14 \\
\hline Above 50 & 21 & 1.95 & 0.8426 & 43.21 \\
\hline Total & 100 & 2.15 & 0.7914 & 36.81 \\
\hline
\end{tabular}

Table 4 shows the variations in the attitude level of employees belonging to different age groups towards the quality of work life. It is inferred that the variations in the attitude level was high among the respondents belonging to above 50 years followed by the age group upto 30 years and $31-40$ years.

Table 5: Education and Variations in the Attitude

\begin{tabular}{|l|c|c|c|c|}
\hline $\begin{array}{l}\text { Educational } \\
\text { Status }\end{array}$ & $\begin{array}{l}\text { No. of } \\
\text { Respondents }\end{array}$ & $\begin{array}{l}\text { Average } \\
\text { Attitude Score }\end{array}$ & $\begin{array}{l}\text { Standard } \\
\text { Deviation }\end{array}$ & $\begin{array}{l}\text { Co- } \\
\text { variation }\end{array}$ \\
\hline Up to H.Sc & 55 & 2.10 & 0.7786 & 37.08 \\
\hline Diploma / ITI & 21 & 2.28 & 0.7643 & 33.52 \\
\hline Degree & 13 & 2.38 & 0.4772 & 20.05 \\
\hline $\begin{array}{l}\text { Postgraduation and } \\
\text { above }\end{array}$ & 11 & 1.81 & 0.8327 & 46.07 \\
\hline Total & 100 & 2.15 & 0.7914 & 36.81 \\
\hline
\end{tabular}

Source: Primary Data 
Table 5 shows the variations in the attitude level of employees belonging to different educational status towards quality of work life in Garment Companies in Salem. It is inferred that the variations in the attitude level was high among the respondents belonging to post-graduation and above qualifications followed by respondents having upto H.Sc qualification.

Table 6: Cadre and Variations in the Attitude

\begin{tabular}{|l|c|c|c|c|}
\hline Cadre & $\begin{array}{l}\text { No. of } \\
\text { Respondents }\end{array}$ & $\begin{array}{l}\text { Average } \\
\text { Attitude Score }\end{array}$ & $\begin{array}{l}\text { Standard } \\
\text { Deviation }\end{array}$ & $\begin{array}{l}\text { Co- } \\
\text { variation }\end{array}$ \\
\hline Managerial personnel & 7 & 2.14 & 0.8288 & 38.72 \\
\hline $\begin{array}{l}\text { Clerical and } \\
\text { Supervisory staff }\end{array}$ & 14 & 2.21 & 0.7722 & 34.94 \\
\hline Workmen & 79 & 2.13 & 0.7913 & 37.15 \\
\hline Total & 100 & 2.15 & 0.7914 & 36.81 \\
\hline
\end{tabular}

Source: Primary Data

Table 6 shows the variations in the attitude level of employees belonging to different cadres towards quality of work life in In Garment Companies in Salem It is inferred that the variations in the attitude level was high among managerial personnel followed by clerical \& supervisory staff.

Table 7: Salary and Variations in the Attitude

Source: Primary Data

\begin{tabular}{|l|c|c|c|c|}
\hline Salary (in Rs.) & $\begin{array}{c}\text { No. of } \\
\text { Respondents }\end{array}$ & $\begin{array}{c}\text { Average } \\
\text { Attitude Score }\end{array}$ & $\begin{array}{c}\text { Standard } \\
\text { Deviation }\end{array}$ & $\begin{array}{c}\text { Co- } \\
\text { variation }\end{array}$ \\
\hline 7500 and below & 30 & 2.06 & 0.7713 & 37.44 \\
\hline $7501-10000$ & 46 & 1.97 & 0.7367 & 37.39 \\
\hline $10001-12500$ & 13 & 2.46 & 0.8421 & 34.23 \\
\hline Above 12500 & 11 & 2.72 & 0.6149 & 22.60 \\
\hline Total & 100 & 2.15 & 0.7914 & 36.81 \\
\hline
\end{tabular}

Table 7 shows the variations in the attitude level of employees belonging to different salary groups with the quality of work life. It is inferred that the variations in the attitude level was high among the respondents belonging

to the salary range of below Rs. 7500 followed by employees belonging to the salary range of 750112500 .

\section{Conclusion}

The quality of work life approach considers human as 'asset' to the organization rather than 'costs'. Employees should love their work and love the place they work with the quality of work life. Better quality of work life promotes human dignity and growth, collaborative work, compatibility of people, organizational goals, etc. Only when the right ambience is provided to the employees, they will be able to deliver their goods effectively and efficiently. As a result, employees become satisfied, motivated, involved and committed individuals with respect to their lives at work. Majority of the employees are being closely associated with every efforts of the company. However, a small segment of workforce had few problems with the quality of work life. The researcher has suggested suitable measures for improving the quality of work life

\section{References}

1. Ahmed, N (1981). "Quality of Work Life: A Need for Understanding”, Indian Management, Vol.20, No.1, pp.2933.

2. Ayesha Tabassum, Tasnuva Rahman and Kursia Jahan (2011). "Comparative Analysis of Quality of Work Life among the Employees of Local Private and Foreign Commercial Banks in Bangladesh", World Journal of Social Sciences, Vol.1, No.1, March, pp.17-33.

3. Bhuvaneswari, P, Suganya, N.S and Vishnupriya, K (2012). "A Study on Quality of Work Life among Employees in Neyveli Lignite Corporation Limited, Tamil Nadu", Research Journal of Commerce \& Behavioural Science, Vol.1, No.4, February, pp.29-32.

4. Cummings, T.G and Worley, C.G (1997). Organization Development and Change, Ohio: South-Western College Publishing, pp.303-304.

5. Cunningham, J.B and Eberle, T (1990). "A Guide to Job Enrichment and Redesign, Personnel, Vol.67, pp.56-61.

6. Danna, K and Griffin, R. W (1999). "Health and Wellbeing in the Workplace: A Review and Synthesis of the Literature", Journal of Management, Vol.25, pp.357-384.

7. Feuer, D (1989). "Quality of Work Life: A Cure for All Ills?" Training: The Magazine of Human Resources Development, Vol.26, pp.65-66.

8. P.Marishkumar, "Problems and Prospects of the Rural Women Entrepreneurs in India", International Research Journal of Human Resources and Social Sciences, ISSN(P): (2394-4218), Vol. 4, Issue 4, April 2017, pp 4352

9. Greenverg, J and Baron, R (1995). Behaviour in Organization, New Jersey: Prentice-Hall. 
10. Jagadeesh Chandran, G and Baby, M.D (2010).

"Measurement and Improvement of Quality of Work Life",

Southern Economist, Vol.48, No.19, February, pp.47-50.

11. Ka Wai Chan and Wyatt Thomas, A (2007). "Quality of

Work Life: A Study of Employees in Shanghai”, Asia

Pacific Business Review, Vol.13, No.4, October, pp.501-

517. 